\title{
RENOVATION OF ROOF STRUCTURE OF HISTORICAL BUILDING - CASE STUDY
}

\author{
Ing. Marcela Spišáková, PhD. ${ }^{1}$; Ing. Daria Mokrenko ${ }^{1^{*}}$ \\ ${ }^{1}$ Technical University of Košice, Faculty of Civil Engineering, Vysokoškolská 4, 04200 Košice, Slovakia \\ * corresponding author: daria.mokrenko@tuke.sk
}

\begin{abstract}
On the present, the problem of renovation of historical buildings is becoming more and more actual. The role of society is to protect and renovate the historical monumets. The presented article focuses on the problem of renovation of historic buildings from a structural, technological and cost point of view. During the solution of the case study "Renovation of roof structure of the Old Town Hall in Košice", a variant solution of the historic roof renovation was designed in accordance with the principles of historical buildings renovation. Subsequently, the evaluation of the technological and cost parameters for renovation; and determination of the optimal variant for renovation of the historical roof was processed through the methods of multicriterial analysis.
\end{abstract}

Key words: Renovation, historical building, roof, wooden construction, Old Town Hall, BIM, technological point, cost point, structural point, multicriterial analysis.

\section{INTRODUCTION}

Renovation of buildings and monuments are of great importance in preserving the historical heritage. Renovation and renovation are necessarily for historic buildings that have worn out over a long period of operation and have lost their unique properties as a result. [1]. Renovation can be complete or partial, depending on the degree of damage. The presented paper is focused on the partial renovation renovation of the roof structure of the historic building «Old Town Hall», which is located in the city of Košice, Slovakia.

As part of the building renovation proposal, it is necessary to find out the contemporary state of the solved building. However, there is project documentation for a specific building, it is necessary to carry out the documentation of the contemporary state, because some previous construction works may not be included in the project documentation. For this purpose, it is possible to use a unique approach to focus on the contemporary state of the building, namely 3D laser scanning technology and also aerial photogrammetry. [2].

\section{RESEARCH MATERIAL AND METHODOLOGY}

The aim of this paper is to propose the renovation of the roof structure of the historic building 'Old Town Hall' in Košice. The contemporary state of the historical building was solved by the 3D laser scanning which presents a latest approach for processing of project documentation of contemporary state of the building. 


\subsection{Research material}

This paper will be implemented on the basis of information about the Old Town Hall (OTH) building in Košice, Slovakia (Fig.1). The building is located in district Košice - Stare Mesto, on the corner of Hviezdoslavova and Strojárenská streets [3].

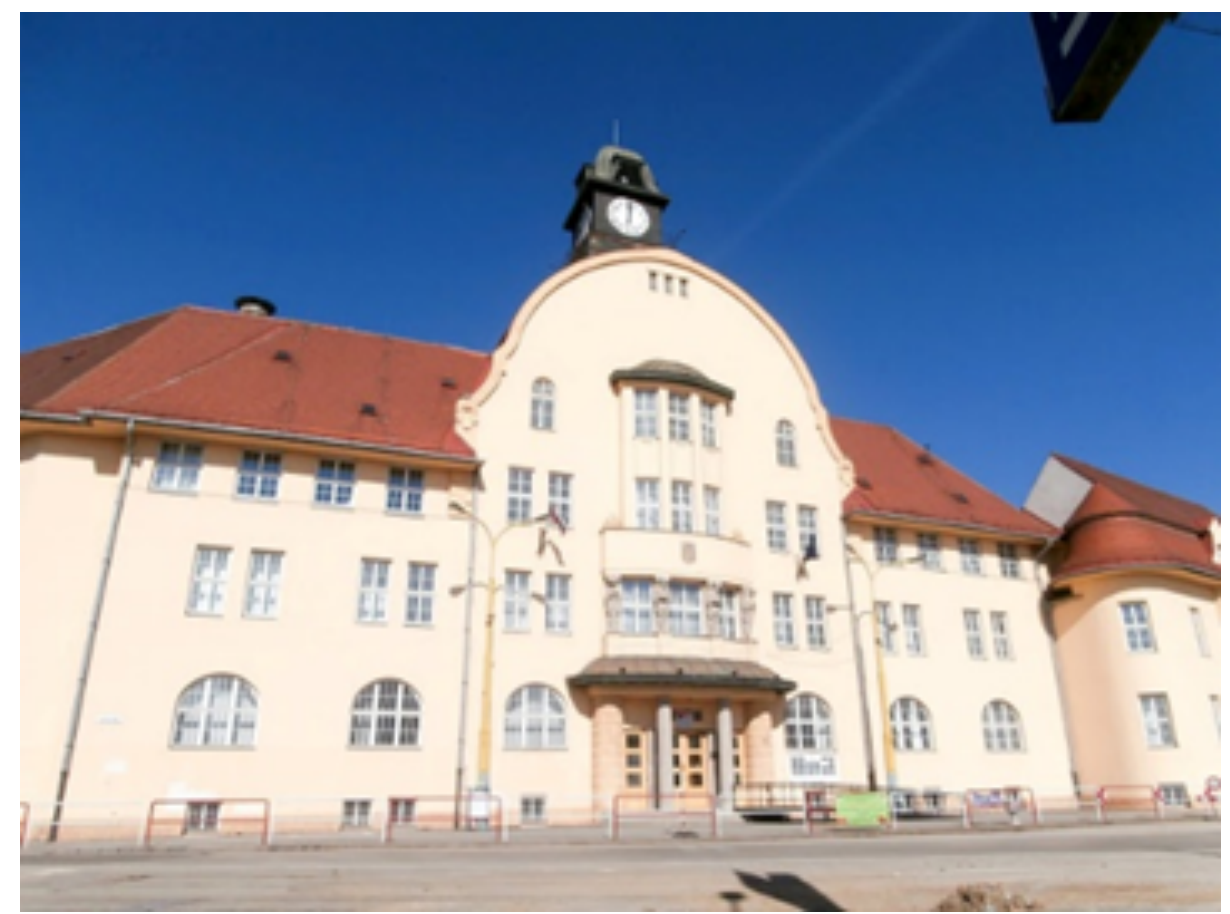

Fig. 1 Old Town Hall [4]

The building was built in 1912-1914. The roof of the building consists of several materials. Above the highest central part, the saddle is terminated by triangular shield, above the risalit, large shields are inserted on both sides, passing into the mass of the roof by a half-shell, above them a superstructure of a clock tower with a sheet metal roof. Roof is accessible from the last floor hallway. The construction of the slope roof structure is a standing chair. Roof covering is ceramic tile, plain tile. The gable roof is on external roof sections: on the east side are inserted gable shields, on the west side are hemisphere and hipped roof. The gable roof and hip roof are on the wings of building. There is the same roofing than on the central part.

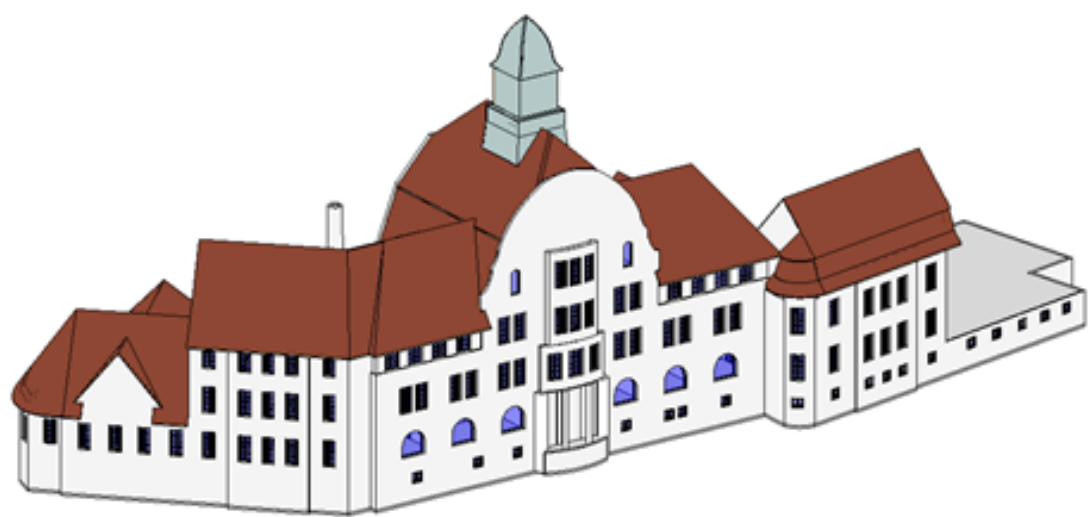

Fig. 2 3D model of OTH from the south side in REVIT software 


\section{Determination of the building contemporary state}

The FARO Focus 3D X130 3D scanner was used to determine the contemporary state of the building roof structure. The 3D slope roof structure model was created in the REVIT software (Fig.2) based on 3D scanning (by point cloud). Through the detailed processing of the 3D model, it was found that OTH slope roof structure is formed by 1031 elements (Fig. 3). The eastern part of the building has not been solved. There is an office of the President of the Slovak Republic. Due to this, for security reasons we were not allowed to access into this space for the processing of contemporary state of the building.

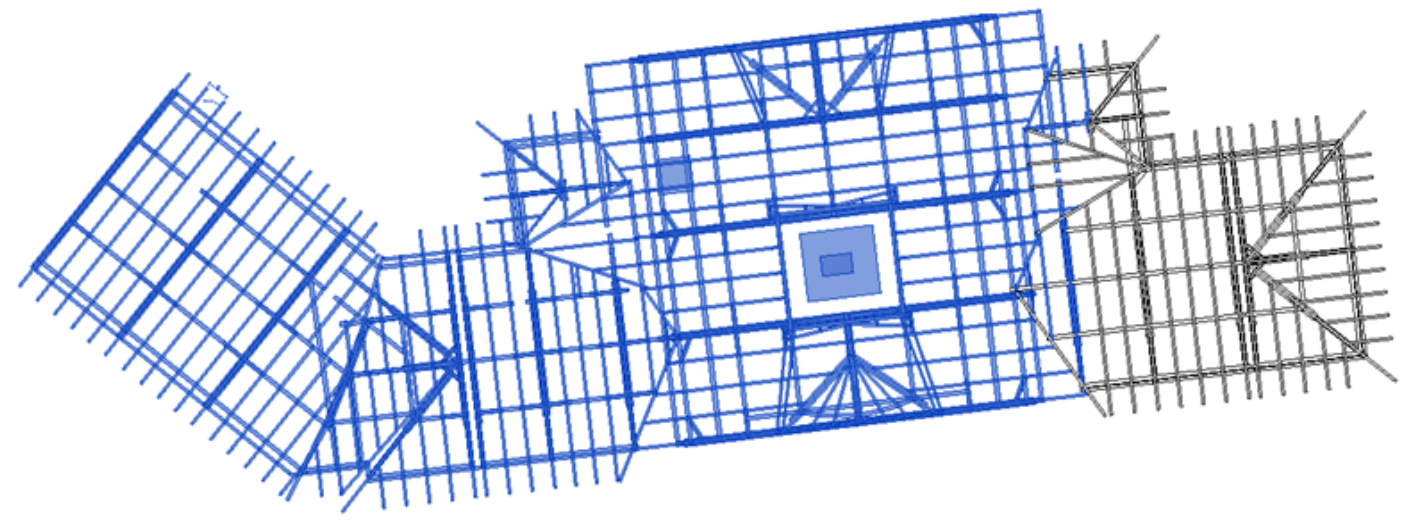

Fig. 3 Drawing of the building "Old Town Hall" roof

\subsection{Research methodology}

The methodology of the work was divided into an analytical research and a practical part - a professional design of the slope roof structure renovation supported by a 3D model of the building (Fig. 4).

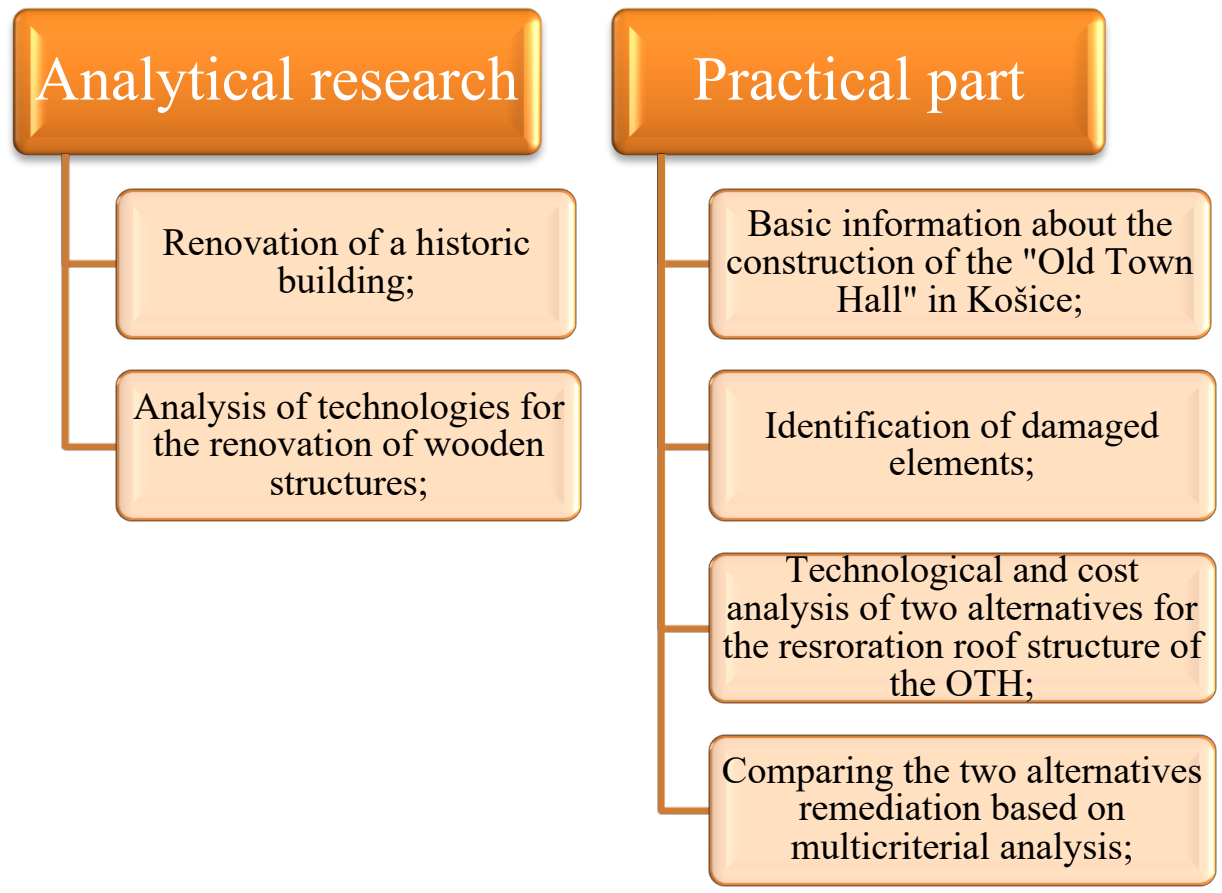

Fig. 4 Work methodology 
The analytical research includes an analysis of information related to the renovation of historic buildings, which describes the data as an approach to renovation, processing of knowledge related to the preservation of the historic building. The practical part included processing of the slope roof contemporary state structure by 3D laser scanning, description of the building, determination of the damage degree of the roof structure and subsequent description of the damaged elements in terms of statics, humidity conditions. These steps resulted in the design of options for the recovery of damaged elements. Specifically, it has been proposed 2 alternatives recovery of damaged elements. Based on the technological and cost analysis of both alternatives, evaluation parameters were acquired, which were subsequently used in multi-criteria evaluation using the method of index coefficients. In conclusion, according to the distribution of weights criteria it was determined optimal variant roof renovation of historic buildings "Old Town Hall" in Košice.

\section{RESULTS AND DISCUSSION}

The results of solution are divided into four process steps: identification of damaged elements, design of remediation of damaged elements, determination the cost, time and technological parameters of decontamination design, selection of optimal remediation technology.

\subsection{Identification of damaged elements}

After strength tests, it was found that the wooden slope roof structure has 25 damaged elements that do not meet the strength standard requirements of STN EN $408+$ A1. After moisture tests, it was found that the roof has 58 damaged elements.

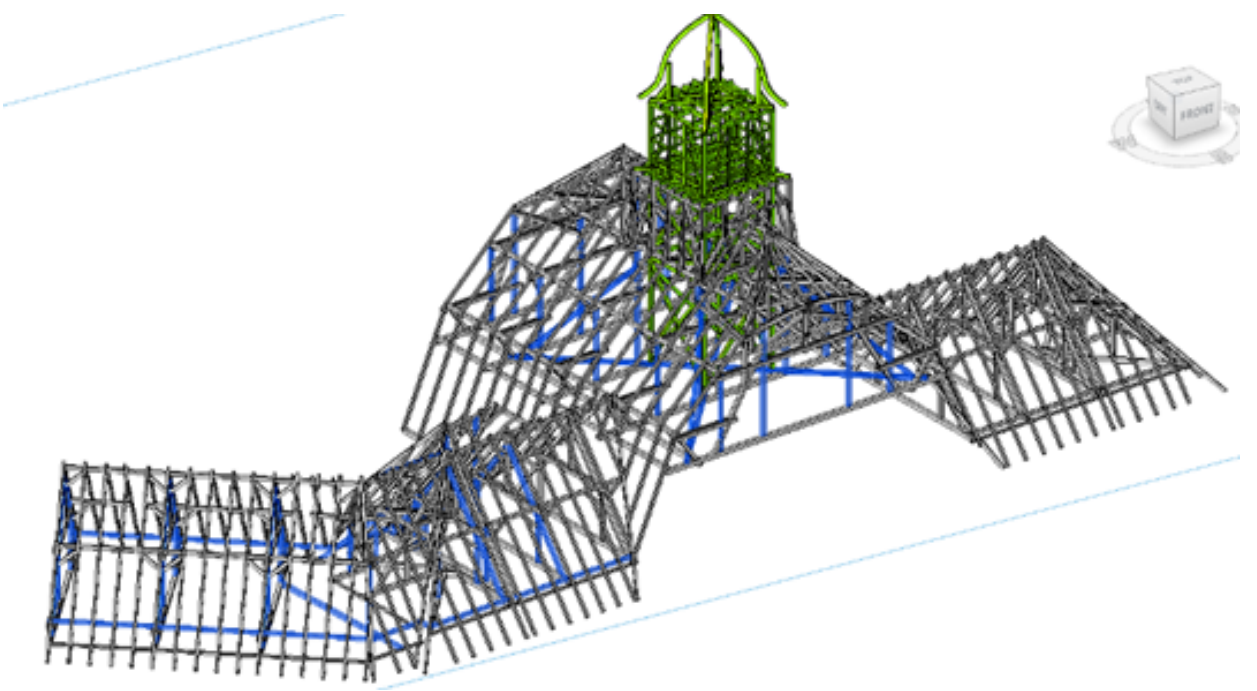

Fig.5 3D model of the OTH roof, damaged elements shown in blue, southern view

\section{Description of damaged elements in terms of static parameters}

\section{Purlins}

All damaged purlins were damaged due to strong pressure of rafters. The results of the strength tests showed that the purlins were 1.4-2.4 times more stressed than specified by the standard requirement. This happened because the rafter exceeds the roof limit of 2.5 meters and the purlin is the last support point of rafters. As a result based on a static calculation, all purlins have a sag about $8 \mathrm{~cm}$. 


\section{Columns}

The columns supporting the both sides of purlins, are deformed for the same reasons as purlins. They are 2.2-2.6 times more stressed than specified by the standard requirement.

\section{Tie beam}

The damaged tie beam on the OTH roof has a critical load due to the fact that during the last reconstruction of the OTH roof in 1978. The supporting structure of the roof was changed and in some places the elements were not replaced by new elements but old ones with suitable dimensions. However, these elements were adapted to some functions, but now they had to perform completely different functions and there were notches in them that previously performed some original function. Over time, due to notches, this element has lost its load-bearing capacity. Again, we can state that as a result, this structural element was loaded 36 times more from the standard at the location of the notches.

\section{Support beams}

The support beams were overloaded up to 2.2 times more than required by the standard.

\section{Description of damaged elements in terms of moisture parameters}

Moisture tests were performed on the OTH roof only visually. Elements that were marked as damaged in terms of moisture were selected on the basis of visible signs of moisture, mold and the formation of wood-destroying fungi. These features were shown by 40 structural elements - column and 18 elements - braces.

\section{Example Analysis of the damaged element - purlins}

For each damaged element, was processed a "Sheet of damaged element", which contained:

- exact specification of damaged elements - element number, dimension, type of damage, place of damage and results of strength test (Tab.1),

- spatial identification of the damaged element in 3D model of the OTH slope roof structure (Fig.6),

- photo documentation of the damaged element (Fig.7),

- design of remediation technology of the damaged element.

\begin{tabular}{|l|l|l|l|l|}
\hline $\begin{array}{l}\text { Element } \\
\text { number }\end{array}$ & $\begin{array}{l}\text { Element } \\
\text { dimensions }\end{array}$ & Type of damage & $\begin{array}{l}\text { Place of } \\
\text { damage }\end{array}$ & Results of strength test \\
\hline 1 & $4560 \times 160 \times 160$ & $\begin{array}{l}\text { element } \\
\text { deflection }\end{array}$ & along & $\begin{array}{l}\text { loaded 2.2 times more from the } \\
\text { standard }\end{array}$ \\
\hline 2 & $4600 \times 160 \times 160$ & $\begin{array}{l}\text { element } \\
\text { deflection }\end{array}$ & along & $\begin{array}{l}\text { loaded 2.4 times more from the } \\
\text { standard }\end{array}$ \\
\hline 3 & $4800 \times 160 \times 160$ & $\begin{array}{l}\text { element } \\
\text { deflection }\end{array}$ & along & $\begin{array}{l}\text { loaded 2.4 times more from the } \\
\text { standard }\end{array}$ \\
\hline 4 & $2700 \times 160 \times 160$ & $\begin{array}{l}\text { element } \\
\text { deflection }\end{array}$ & along & $\begin{array}{l}\text { loaded } 1.8 \text { times more from the } \\
\text { standard }\end{array}$ \\
\hline
\end{tabular}

Tab. 1 Description of purlins 


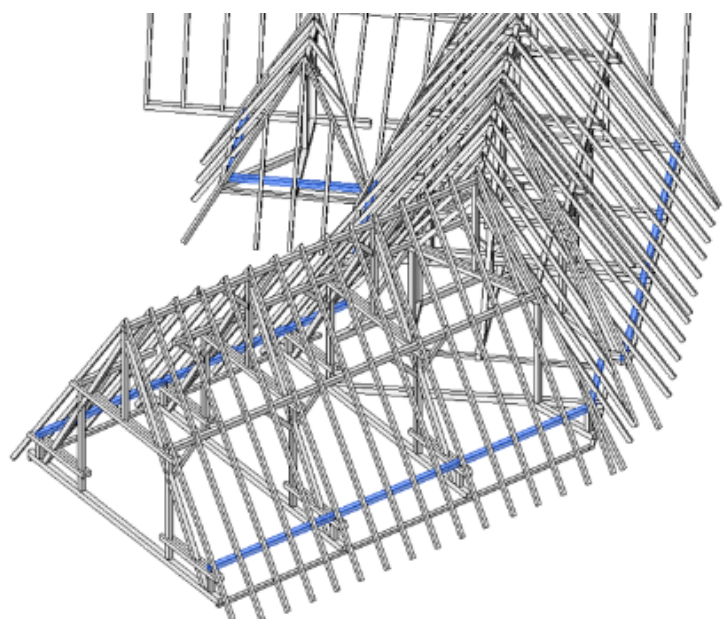

Fig. 6 Spatial identification of a damaged element in 3D model of the OTH slope roof structure

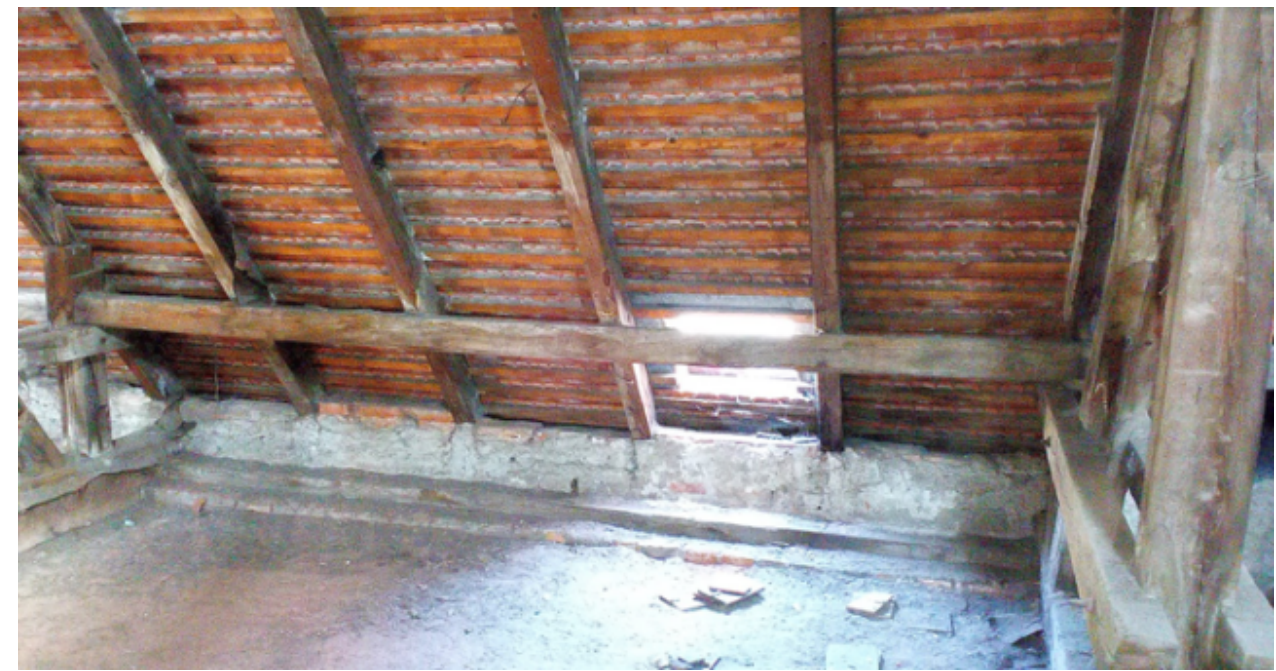

Fig. 7 Photo documentation of the damaged element (purlins)

For damaged purlins were proposed two possible options for recovery:

1. Supporting purlins with wooden elements

2. Supporting purlins with steel elements

\subsection{Proposal for renovation of damaged slope roof structure elements}

They were proposed two alternative methods for the renovation of damaged slope roof structure elements (Tab. 2). The first alternative makes it possible to preserve all the original elements of the roof and treat the contemporary state, by removing critical damage by non-destructive renovation methods. The second alternative is more laborious, but will allow the slope roof structure to be saved from damage for longer than in the first alternative. 


\begin{tabular}{|c|c|c|}
\hline Element & 1. renovation alternative & 2. renovation alternative \\
\hline \multicolumn{3}{|c|}{ Static damage } \\
\hline Purlins & $\begin{array}{l}\text { Supporting purlins with wooden } \\
\text { elements }+ \text { chemical treatment }\end{array}$ & $\begin{array}{l}\text { Supporting beams with steel elements }+ \\
\text { chemical treatment of new parts }\end{array}$ \\
\hline Columns & $\begin{array}{l}\text { Supporting the purlins with wooden } \\
\text { elements makes it possible to repair } \\
\text { several damaged parts next to each other } \\
+ \text { chemical treatment }\end{array}$ & $\begin{array}{l}\text { Exchange of columns }+ \text { chemical } \\
\text { treatment of new parts }\end{array}$ \\
\hline Tie beam & \multirow{2}{*}{$\begin{array}{l}\text { Lining with wooden elements }+ \\
\text { chemical treatment }\end{array}$} & $\begin{array}{l}\text { Prosthesis }+ \text { chemical treatment of new } \\
\text { parts }\end{array}$ \\
\hline Support beams & & $\begin{array}{l}\text { Replacement of supporting beams }+ \\
\text { chemical treatment of new parts }\end{array}$ \\
\hline \multicolumn{3}{|c|}{ Moisture damage } \\
\hline $\begin{array}{l}\text { Columns + } \\
\text { Braces }\end{array}$ & $\begin{array}{l}\text { Strain measurement }+ \text { chemical } \\
\text { treatment }\end{array}$ & $\begin{array}{l}\text { Exchange of damaged elements }+ \\
\text { chemical treatment of new parts }\end{array}$ \\
\hline
\end{tabular}

Tab. 2 Summary table

\subsection{Analysis of cost, time and technological parameters of renovation design}

The cost analysis was processed in the construction and economic software CENKROS 4. The analysis of technological and time parameters of individual alternatives was performed through a time schedule, which is processed in the MS Project program.

\section{Time and technological analysis}

The start of the implementation of the renewal of the slope roof structure of the OTH 1st alternative is planned for 10.6.2019 and the end on 30.7.2019. The first stage will be preparatory work, second one the thermosanation process. After thermosanation, the removal of the roofing will begin. Next will be the stages of repair and installation of ceramic roofing, supporting beams, attaching tie beams, chemical treatment of the slope roof structure. Finally, the finishing works will be carried out. The entire renovation will take 37 days.

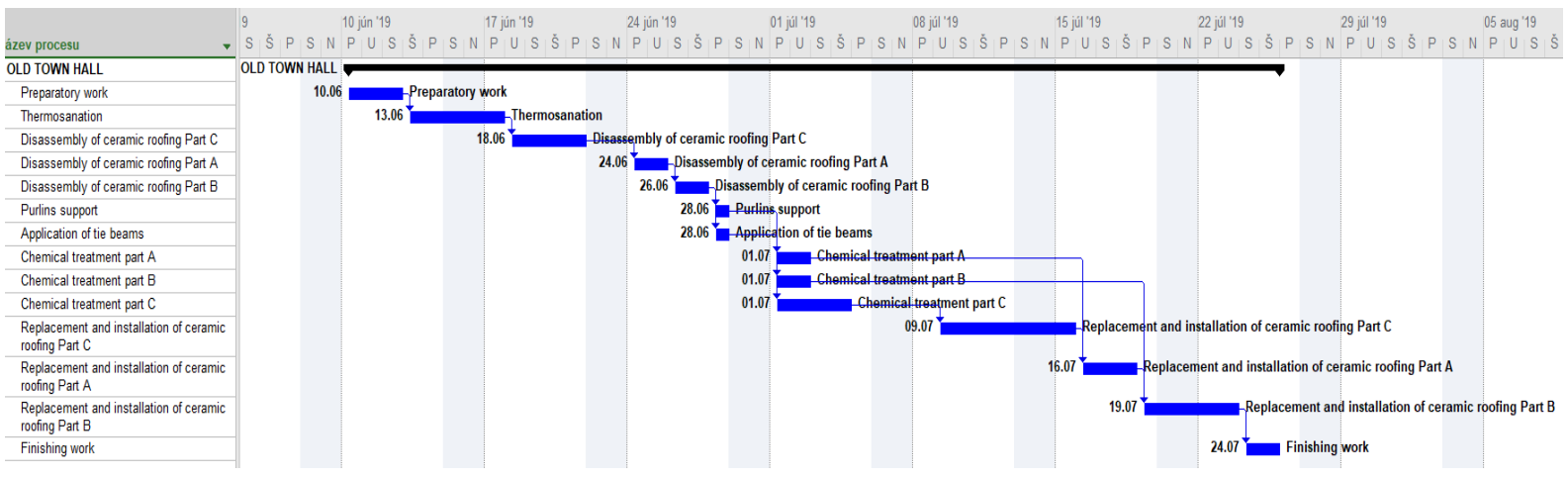

Fig. 8 timeline of the 1st recovery alternative

The start of the implementation of the renewal of the slope roof structure of the OTH 2 nd alternative is planned for 10.6.2019 and the end on 14.8.2019. The first stage will be preparatory work and then the original ceramic roofing will be a dismantling. Then it will realize installation of ceramic coverings. 
Next will be the stages of supporting slope roof structure, replacement of hangers, prosthesis of tie beams with steel bars, replacement of support beams, replacement of braces, chemical treatment. Finally, the finishing works will be carried out. The entire renovation will take 48 days.

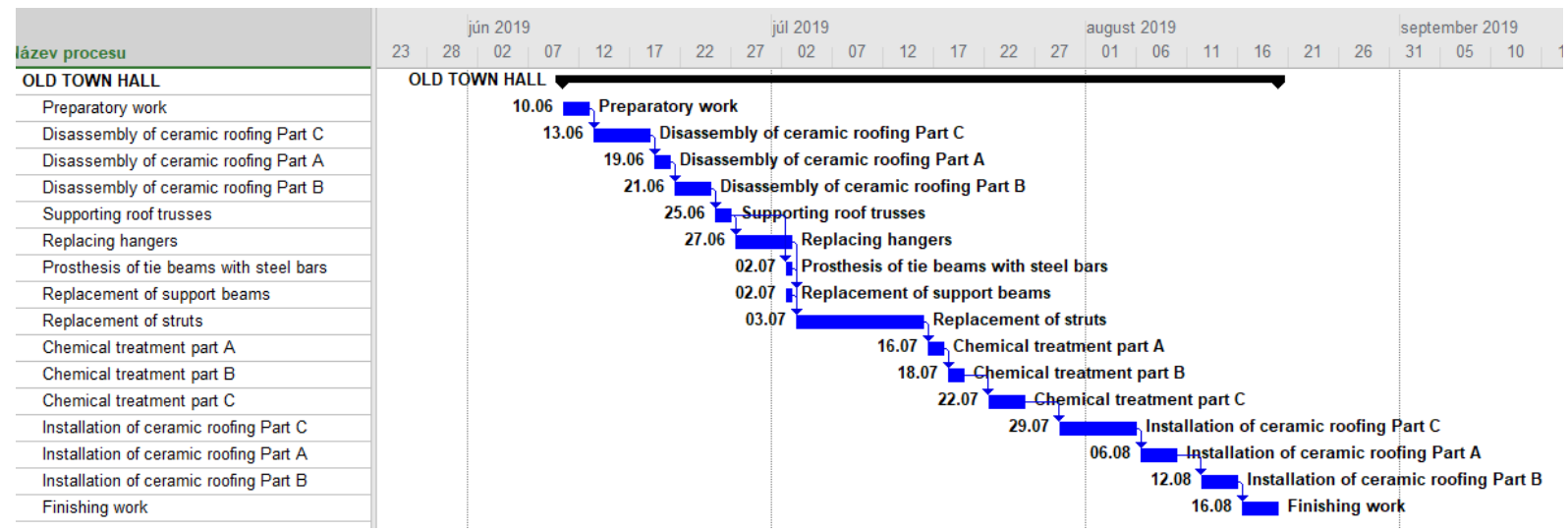

Fig. 9 timeline of the 2nd recovery alternative

\section{Cost analysis of decontamination design}

The total cost of reconstruction the slope roof structure of the 1st alternative was $€ 30,221.98$ and the total cost of reconstruction the 2nd alternative slope roof structure was $€ 82,126.93$.

Such a difference in the price of slope roof structure renovation was due to the fact that, firs alternative is more laborious than second alternative. The results of the analysis parameters both recovery alternatives are shown in Table 3.

\begin{tabular}{|l|l|l|}
\hline Decontamination alternative & Total renovation costs $(\boldsymbol{€})$ & Duration of renovation (days) \\
\hline $\mathbf{1 .}$ & $30221,98 €$ & 37 days \\
\hline $\mathbf{2 .}$ & $82126,93 €$ & 48 days \\
\hline
\end{tabular}

Tab. 3 Summary table of technological, time and cost analysis

\subsection{Choosing the optimal renovation technology}

The choosing of the optimal renovation technology was carried out through of a multi-criteria analysis. The importance of individual criteria for the selection of the optimal alternative for OTH slope roof structure renovation is based on the opinions of 29 respondents who identified each criterion in their own opinion. Subsequently, the weights of the criteria were determined, which determine the importance of the meaning of the individual criteria. The sum of all the weights of the criteria was the sum $=1$. 


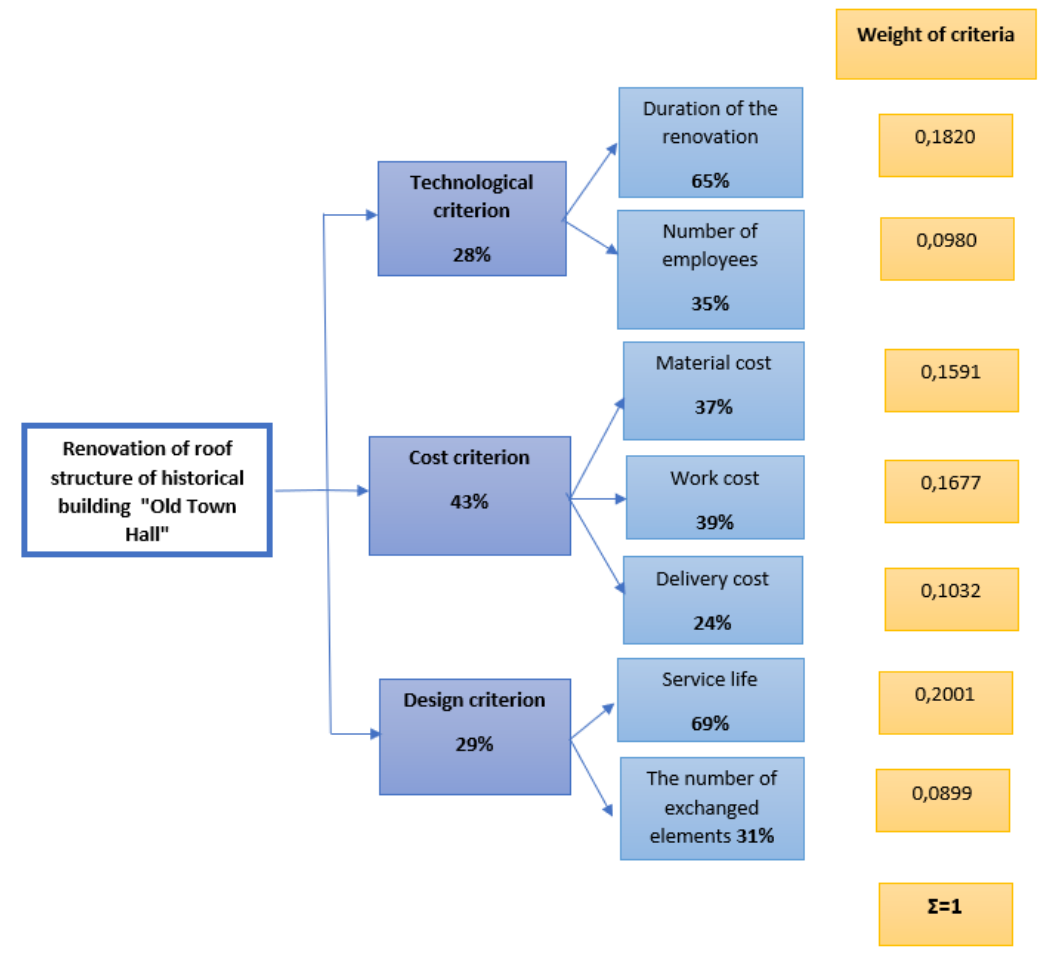

Fig. 9 Evaluated hierarchical branched graph of tree type

The total efficiency was determined for each variant of the evaluation object. The optimal variant was reaches the maximum value of total efficiency. The index coefficient method was used to calculate the total efficiency. The highest level of efficiency is achieved by the 1st alternative, when evaluated on the basis of given conditions, it is optimal. Alternative 2 is less effective. The second alternative was more expensive than the first due to the complete replacement of damaged elements. On the other hand, a complete replacement of damaged elements would increase the operating time of the slope roof structure, but by determining the overall efficiency and effectiveness of these alternatives, a lower price and recovery time would allow the slope roof structure to look like its original appearance, which proved to be a crucial criterion.

\section{CONCLUSION}

Renovation of historic buildings is a complex and important task requiring special skills and abilities, as well as certain sustainable approaches in architecture, construction and engineering. Renovation should eliminate structural deficiencies, prolong the service life and not deteriorate the technical or aesthetic condition of the building. The basic step in the renovation of buildings is to determine the contemporary state of the solved building. The contemporary state can be obtained by the method of 3D laser scanning. Subsequently, we can use laser scanning to obtain a basis for project documentation, which in many cases is missing in historic buildings. The 3D laser scanner will create a point cloud, where we can obtain a 3D model of the building using suitable software. Subsequently, it is possible to process a 4D analysis of the object - time analysis, for example in the Naviswork software. In the next phase, it is possible to work into the 5D and 6D interface of the building model, which means the economic analysis and sustainability of the building. It follows that laser scanning can be considered as one of the supporting tools in creating a BIM model of historic buildings that do not have project documentation. 
In this article, the technology of renovation of a part of the roof structure of the historical building "Old Town Hall" in Košice was proposed. Based on the analysis of damaged elements, 2 remediation alternatives were developed, for which an analysis of technological, time and cost parameters of remediation methods was prepared. The first alternative makes it possible to preserve all the original elements of the roof and treat the original condition, by removing critical damage by non-destructive remediation methods. The second alternative is more laborious, but will allow the slope roof structure to be saved from damage for longer than in the first alternative.

Subsequently, the two alternatives were compared to determine the optimal variant. The total costs of implementing these two alternatives and the time required to renovate all roof elements were compared. Based on the cost analysis, it was found that the total cost of restoring the slope roof structure of the 1st alternative is three times less than in the 2nd alternative. The analysis of technological parameters of individual alternatives was performed through a time schedule. The slope roof structure recovery time of alternative 1 is less than in alternative 2 . It was found that the highest level of efficiency is achieved by the 1st alternative, when evaluated on the basis of given conditions is optimal. 2 alternatives are less effective. The second alternative was much more expensive than the first due to the complete replacement of damaged elements, which would increase the operating time of the slope roof structure. But based on the determination of the overall efficiency and effectiveness of these alternatives, a lower price and renewal time would allow the original appearance of the slope roof structure to be maintained, which proved to be a decisive criterion. The priority of the renovation of this building was to choose such a technology that would allow to preserve the original state of the historic building "Old Town Hall" in accordance with the principles of renovation of historic buildings.

\section{Acknowledgment}

This paper presents a partial result of project "VEGA 1/0557/18 Research and development of process and product innovations of modern construction methods in the context of principles Industry 4.0". 


\section{References}

[1] Evseeva E; Berdnik T., The significance of restoration and reconstruction of material culture in historical heritage preservation. The typology and methods of reconstruction and restoration. [Online] [viewed date: 22 january 2021]. Available from: $<$ https://nauchforum.ru/conf/philology/vi/22059>

[2] Gregor, M.; Štefánik, A.; Furmann, R.; Medvecký, Š.; Mačuš, P., 3D laserové skenovanie vel'kých objektov. 1.vydanie, CEIT, Žilina, Slovensko, 2016. ISBN 978-80-971684-9-0

[3] Pamiatkový úrad Slovenskej Republiky, Pamiatkový objekt - podrobnosti, [Online] [viewed date: 22 january 2021]. Available from: $<$ http://www.pamiatky.sk/po/po/Details?id=18704>

[4] Radnica Starého města, [Online] [viewed date: 14 may 2020]. Available from: $<$ https://4.bp.blogspot.com/>

[5] M. Kolcun, M. Bon. Potulky po meste Košice, 1. vydanie 2003. ISBN 8089054129

[6] Schunck E.; Oster H.; Barthel R.; Kiessl K. Atlas striech. Šikmé strechy. 2003. ISBN 8088905559

[7] Jan Vinař a kol. Historické krovy. Typologie, průzkum, opravy, 1. vydanie, Praha, Grada Publishing 2010. ISBN 978-80-247-3038-7

[8] Oto Makýš, Technológie pre rekonštrukcie, vyd. Jaga, 2002. ISBN 9788088905318

[9] Renáta Bašková, Ekonomicko-matematické metódy - čast' I. lineárna optimalizácia a siet’ová analýza. Technická univezita, 2004. ISBN 8080731888, 9788080731885

[10] Kašpar, M.; Pospíšil, J.; Štrouner, M.; Křemen, T.; Tejkal, M. Laserové skenovací systémy ve stavebnictví. 1.vydanie. Vydala Vega s.r.o. 2003. ISBN 80-900860-3-9

[11] DBN A.2.2-14-2016 Zloženie a obsah vedeckej projektovej dokumentácie na obnovu architektonických pamiatok. 206

[12] DBN B.3.2-2-2009 Rekonštrukcia, oprava, obnova stavebných objektov. Obytné budovy. Rekonštrukcia a väčšie opravy. 2009

[13] Alexandrova, V.; Pastuchov, U.; Rasina, T. Technológia a organizácia rekonštrukcie budov. Petrohrad. 2011. ISBN 978-5-9227-0294-2

[14] Koršever, N. Strešné zariadenie. 2008. ISBN 5-9533-0467-6, 978-5-9533-0467-2

[15] Pamiatkový úrad SR. Vademekum vlastníka kultúrnej pamiatky, vlastníka nehnutel’nosti v pamiatkovom území a ochrannom pásme, vlastníka a správcu hnutel'ností v sakrálnom objekte. Bratislava. 2017. ISBN 978-80-89175-71-0 